
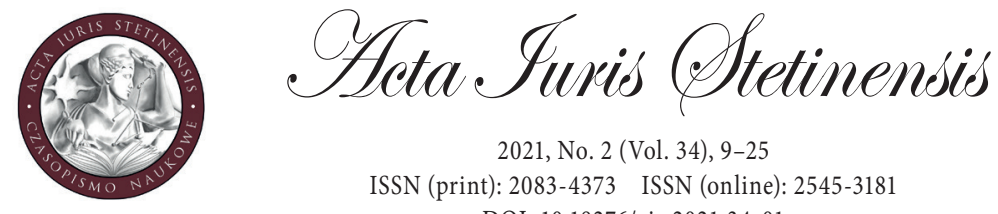

2021, No. 2 (Vol. 34), 9-25

ISSN (print): 2083-4373 ISSN (online): 2545-3181

DOI: $10.18276 /$ ais.2021.34-01

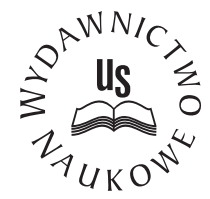

Łukasz Bernaciński

Ph.D. student

University of Lodz, Poland

e-mail: lukasz.bernacinski@edu.uni.lodz.pl

ORCID: 0000-0002-3491-8675

\title{
Assessment of the transparency of the functioning of the Church Fund in Poland in terms of granting it
}

\begin{abstract}
This paper attempts to assess the transparency of the Church Fund's operations in the area of awarding grants for the maintenance and renovation of historic sacred buildings and for supporting socially useful ecclesiastical activities. For this purpose, the author has outlined the procedure for awarding grants from the Church Fund by the Minister of the Interior and Administration. The author has also presented the practice of secretly increasing the budget of the Church Fund during the financial year, as observed in recent years, and the problem of not publishing decisions on awarding grants insofar as they concerned the distribution of funds from the said increase in the Fund's budget. Basic measures have been proposed to potentially contribute to increasing the transparency of the granting procedure and to build citizens' trust in the State. The area related to the financing of the Church Fund should be considered as non-transparent. On the other hand, the transparency of the grant award procedure is given credit for it is transparent, albeit apparently quite complicated, and is communicated to applicants in a comprehensible manner.

When presenting the said procedure and assessing the functioning of the Church Fund in this respect, the author analyses and interprets the current provisions of the constitutional, statutory and sub-statutory rank laws in force applicable to the subject matter. Incidentally, elements of the historical overview of applicable laws are also used.
\end{abstract}

Keywords: grants, public funds, Church Fund, transparency 


\section{Introduction}

The Church Fund was established under the Act of 20 March 1950 on property in mortmain, the guarantee of arable farms to parish priests and on the establishment of the Church Fund (Dz.U. (Journal of Laws) No. 9, item 87, hereinafter: the Act on property in mortmain) as the equivalent for the ecclesiastical land property nationalised after World War II. ${ }^{1}$ A restitutive measure by design, it was meant to serve as a platform for transferring funds to aggrieved churches and other religious associations. $^{2}$ Apart from numerous irregularities present in the functioning of the Fund from its very establishment ${ }^{3}$ and the evolution of purposes financed by the Fund, grants are still awarded from the Fund's budget to rebuild, maintain and renovate sacred and ecclesiastical facilities of historical value, and to support socially useful ecclesiastical activities (charities, care and education work, as well as initiatives to combat social dysfunctions and the related cooperation between government agencies, the Catholic Church and other churches and religious associations). ${ }^{4}$ At present, in accordance with the constitutional rule of equality of churches and other religious associations ${ }^{5}$, the Fund's support can be enjoyed by a wider group of entities than just aggrieved religious communities. It must be noted that the extension of the right to receive support from the Church Fund to religious communities not

1 J. Koredczuk, Entry: Dotacje państwowe dla zwiazków wyznaniowych, in: A. Mezglewski (ed.), Leksykon prawa wyznaniowego, Warszawa 2014, p. 61.

2 According to Dariusz Walencik, before 1950, legal persons of the Catholic Church owned $168,963.9$ ha of land, compared to only 32,699 ha in 1962 . The difference meant that at least $136,264.9$ ha of rural land had been nationalised. Estimates regarding nationalised ecclesiastical rural land provided in government documents and scientific studies fall within the range between 90,000 ha and 155,000 ha. An opinion by Michał Rynkowski is also known, according to which churches in Poland, including the Catholic Church, "had never been large landowners" but were deprived of a major part of their properties after World War II. For more information, cf. D. Walencik, Nieruchomości Kościoła katolickiego w Polsce w latach 1918-2012. Regulacje prawne - nacjonalizacja - rewindykacja, Katowice 2013, pp. 224-229; D. Walencik, Rewindykacja nieruchomości Kościoła katolickiego w postępowaniu przed Komisją Majątkową, Lublin 2008, p. 147; M. Rynkowski, Państwo i Kościół, in: G. Robbers (ed.), Państwo i kościół w krajach Unii Europejskiej, Wrocław 2007, p. 299.

3 M. Zawiślak, Wydatkowanie środków Funduszu Kościelnego w latach 1950-1989, "Studia z Prawa Wyznaniowego" 2009, vol. 12, pp. 241-266; J. Krukowski, Polskie prawo wyznaniowe, Warszawa 2008, pp. 216-217.

4 Cf. Section 1 of the Statutes of the Church Fund as annexed to Resolution No. 148 of the Council of Ministers of 7 November 1991 on the Statutes of the Church Fund, Monitor Polski (Polish Monitor) No. 39, item 279 (hereinafter the Statutes of the Church Fund).

5 Article 25(1) of the Constitution of the Republic of Poland of 2 April 1997, Dz.U. (Journal of Laws), No. 78, item 483 (hereinafter the Constitution). 
aggrieved by nationalisation of their property seems to be a result the egalitarian understanding of equality which permits no differentiation between the rights held by churches and other religious association through demonstrating, or even not demonstrating at all, features which are relevant to a varying degree. ${ }^{6} \mathrm{~A}$ view is also known according to which extending the circle of entities eligible to draw benefits from the Church Fund is substantiated by implementation of the constitutional principles of equality of churches and other religious associations and cooperation of the State with all religious associations for the individual and the common good (Article 25(3) of the Constitution). ${ }^{7}$

Transparency may be understood as an institution which delineates the boundaries of access to specific information granted to an individual, a specific group of people or the general public. Such delineation should take account of the fact that aspects of transparency include openness which lies at the foundation of public life and democratic rule of law (as well as management of public property). ${ }^{8}$ This is confirmed by the Polish legislator in Article 61(1) of the Constitution which provides that a citizen has the right to obtain information about activities undertaken by public authorities and public servants. This right applies also to obtaining information on activities of economic and professional self-governing authorities as well as other persons and organisational units insofar as they perform tasks of public authority and manage communal assets or State Treasury property.

Transparency of public administration is based primarily on making and enforcing decisions in an open manner and on the grounds and within the limits of applicable law. It should be assumed that openness (or, more broadly, transparency) in public administration is manifested by inter alia ensuring free individual access to information (documents) and keeping the stakeholders informed about the decision-making procedure, the decision-maker in charge and reasons for a particular decision as well as by clarity of the procedures and plain language of decisions and information communicated to the stakeholders. ${ }^{9}$

6 Cf. A.M. Abramowicz, Zasada równouprawnienia związków wyznaniowych w orzecznictwie Trybunału Konstytucyjnego, "Studia z Prawa Wyznaniowego" 2015, vol. 18, pp. 238-240, P. Borecki, M. Pietrzak, Glosa do wyroku TK z dnia 2 kwietnia 2003 r., K 13/02, "Przegląd Sejmowy" 2003, vol. 5, pp. 98-100.

7 A. Mezglewski et al., op. cit., p. 245.

8 For more information, see Sz. Osowski and B. Wilk, Jawność jako zasada demokratycznego państwa prawnego, "Krajowa Rada Sądownictwa" 2016, vol. 4, pp. 27-34.

9 Cf. E. Zielińska, Transparentność, in: J. Itrich-Drabarek (ed.), Encyklopedia administracji publicznej, Warszawa 2018, p. 214. 
The purpose of this paper is to attempt to assess the transparency of operations of the Church Fund in the area of awarding grants from the Fund's budget. To this end, the author outlines the procedure for awarding grants and promulgating grant decisions as well as the recent practice of increasing the Fund's budget during the financial year. The matters in question are assessed from the perspective of the requirement for transparent operations of public administration.

\section{Background information}

The church fund was established under Article 8 of the Act on property in mortmain, as the equivalent for nationalised ecclesiastical rural land. ${ }^{10}$ Only churches and other religious associations aggrieved by nationalization were to be the beneficiaries of the Fund. In practice, the Fund was used throughout the period of the Polish People's Republic as a tool for implementing the state's denominational policy, designed to cause changes in the religious structure of the society. ${ }^{11}$

The Church Fund commenced its operations as late as in September $1951 .{ }^{12}$ The Conference of the Episcopate of Poland's decision not to participate in the Fund's work is inter alia considered as the reason behind the delayed inauguration of the Fund, as a result of which the statutes of the Fund were adopted only on 21 February 1951. Being in conflict with Article 10(3) of the Act on property in mortmain, the statutes were never promulgated. ${ }^{13}$ In accordance with the legislation, the Fund was to be formed by revenues from seized rural land and state subsidies adopted by the Council of Ministers ${ }^{14}$, which were meant to be earmarked solely for ecclesiastical and charity purposes in accordance with the provisions of the Act on property in mortmain. ${ }^{15}$ In practice, since the start of its operations, the Fund has relied only on contributions from the state budget. ${ }^{16}$

10 For more information on the historical and political circumstances accompanying the establishment of the Church Fund see M. Winiarczyk-Kossakowska, Przejęcie przez państwo "dóbr martwej ręki” (W pięćdziesiątą rocznicę), "Państwo i Prawo” 2000, no. 12, pp. 51-65.

11 Cf. A. Mezglewski et al., op. cit., p. 239.

12 M. Zawiślak, Wydatkowanie..., p. 241 with footnotes.

13 M. Winiarczyk-Kossakowska, op. cit., p. 62.

14 Article 8 of the Act on property in mortmain.

15 Article 1(4) of the Act on property in mortmain.

16 In 1990-1996, the Fund had a separate bank account and earned additional, relatively small, sums on bank interests. 
The current form of the Polish system of financing churches and other religious associations from public funds can be divided, after Tadeusz Stanisławski, into three categories - positive, negative and indirect financing. ${ }^{17}$ The essence of positive financing is the direct transfer of funds from the state budget to churches and other religious associations due to religious activities carried out by a religious association, and in the case of natural persons - on account of their having the status of a clergyman. This category includes the financing of the broadly understood pastoral care of uniformed services, including the military pastoral care together with the structure of the Polish Army Field Ordinariate, as well as the activities of the Church Fund in the field of paying some social and health insurance contributions for certain groups of clergy. Expending the funds from the Church Fund in the remaining scope can be considered as the cost of the state related to providing it by churches and other religious associations in the performance of public functions. ${ }^{18}$ Negative financing consists in not burdening the religious associations, in whole or in part, with public tributes, which are collected from other entities in a similar situation. The exemptions mostly concern direct and local taxes, less often indirect ones. ${ }^{19}$ The essence of indirect financing involves the creation by the legislator of such legal mechanisms that will become an incentive for third parties to financially aid churches and other religious associations. This category includes, for example, the basic source of income for religious communities, i.e. offerings (donations made, for example, on the occasion of worship) or the possibility of deducting from the tax base donations made for the purposes of religious worship or church charity and care activities. ${ }^{20}$

The historical legislator set the Fund five goals listed expressis verbis in Article 9(1) of the Act on property in mortmain, but before 1990, the Fund also pursued objectives not described in the normative acts. ${ }^{21}$ After 1990, these goals

17 T. Stanisławski, Sposoby finansowania kościołów i innych związków wyznaniowych ze środków publicznych, in: D. Walencik (ed.), Prawo wyznaniowe w Polsce (1989-2009). Analizy - dyskusje postulaty, Katowice-Bielsko-Biała 2009, pp. 338-340.

18 Cf. P. Stanisz, Bezstronność światopoglądowa władz publicznych a finansowanie związków wyznaniowych, in: T.J. Zieliński (ed.), Bezstronność religijna, światopogladowa i filozoficzna władz Rzeczypospolitej Polskiej, Warszawa 2009, pp. 116-117.

19 T. Stanisławski, Finansowanie instytucji wyznaniowych ze środków publicznych w Polsce, Lublin 2011, pp. 74-91.

20 Cf. R. Mastalski, Prawo podatkowe, Warszawa 2016, pp. 485-487.

21 M. Zawiślak, Wydatkowanie..., pp. 248-253, 258-265. 
were expanded due to the publication of the regulation of the Council of Ministers $^{22}$ and the Statute of the Church Fund. Another change in the catalogue of the Fund's objectives took place on 1 January 1999, with the entry into force of the Act on the social insurance system. ${ }^{23}$ In Article 99 of this act, the legislator decided to delete Article 9(1)(3) of the Act on property in mortmain, stating that the Church Fund will provide coverage for clergy with sickness insurance in justified cases. On the other hand, Article 9(1)(4), referring to a special pension for socially meritorious clergymen, was changed, so that its current wording ensures that the Church Fund will provide for the payment of social insurance contributions for clergy in the amount specified in the Act on the social insurance system. At present, three categories of purposes supported by the Church Fund are named: payments of a part of social and health insurance contributions for certain groups of the clergy, maintenance and renovation of historical sacred facilities, and support of socially useful ecclesiastical activities. ${ }^{24}$ Under Article 10(2) of the Act on property in mortmain, the Council of Ministers was authorised to adopt the Fund's statutes to regulate the organisation of the Church Fund, the manner of establishing its authorities and operating rules. At present, the Fund is supervised by the Minister of Internal Affairs and Administration, who is in charge of the government administration domain of religious denominations and national and ethnic minorities. The Minister is also the administrator of Part 43 of the state budget, i.e. religious denominations and national and ethnic minorities. ${ }^{25}$ Legal support of the Fund is provided by the Department of Religious Denominations and National and Ethnic Minorities (hereinafter: Department) of the Ministry of Internal Affairs and Administration.

The Church Fund was increased in 2010, and then continuously since 2012, it has been increased during financial years by allocation of funds from either the

22 Regulation of the Council of Ministers of 23 August 1990 on extending the scope of the Church Fund's objectives, Dz.U. (Journal of Laws), No. 61, item 354.

23 Act of 13 October 1998 on the social insurance system, consolidated text, Dz.U. (Journal of Laws) of 2020 , item 266.

24 A. Czohara, Podstawy prawne zadań Funduszu Kościelnego w III RP, in: P. Borecki et al. (eds.), Pro bono Reipublicae. Ksiega jubileuszowa Prof. Michała Pietrzaka, Warszawa 2009, pp. 201-202; A. Mezglewski et al., op. cit., pp. 246-248.

25 Section 1 of the Regulation of the Prime Minister of 18 November 2019 on the detailed remit of the Minister of Internal Affairs and Administration, Dz.U. (Journal of Laws), item 2264. 
special-purpose or general reserve of the state budget. ${ }^{26}$ In 2010, the amount of PLN 4,621,000 was allocated from the special-purpose reserve, and since it was higher than the deficit in the Church Fund's budget (related to insufficient funds for implementation of the Fund's principal purpose), PLN 2,150,200 was returned as unused funds. In 2012-2014, the Church Fund's budget remained unchanged and was subsidised each year with PLN 2,125,900, PLN 23,856,000 and PLN 38,769,000 each year respectively. In 2015, although the Fund's budget was increased compared with the previous year, it became necessary to allocate a special-purpose reserve of PLN 9,829,000. In 2016 alone, the Church Fund was awarded three special-purpose subsidies of PLN 3,986,000, PLN 11,434,000 and PLN 11,789,600 respectively. The situation repeated the following year, with subsidies amounting to PLN 8,895,000, PLN 14,805,000 and PLN 1,838,000 respectively. In 2018, the Church Fund's budget was increased during the financial year by PLN $21,190,000 .{ }^{27}$ In 2019 , the budget of the Church Fund was increased nine times (seven times from the general reserve of the state budget and twice from the special-purpose reserve) for a total amount of PLN 29,947,560.41. In 2020, the Fund's budget was increased four times (once from the general state budget reserve) by a total amount of PLN 41,016,090.12. As at 17 March 2021, the Fund's budget for 2021 has not been increased. ${ }^{28}$

Table 1. Comparison of the amount of the budget of the Church Fund provided for in the Budget Act with the data of the Ministry of the Interior and Administration on the amount of the budget of the Church Fund in 2010-202129

\begin{tabular}{|c|c|c|}
\hline Year & $\begin{array}{c}\text { The budget of the Church Fund entered in } \\
\text { the Budget Act (PLN) }\end{array}$ & $\begin{array}{c}\text { Budget of the Church Fund according } \\
\text { to data from the Ministry of Interior } \\
\text { and Administration (PLN) }\end{array}$ \\
\hline 2010 & 86336000 & $86336000+4621000$ \\
\hline 2011 & 89185000 & 89185000 \\
\hline 2012 & 94374000 & $94374000+2125900$ \\
\hline
\end{tabular}

26 Efforts to transfer the Church Fund assets to Part 83 Earmarked reserves within the Budget Act. Cf. D. Walencik, Wydatkowanie środków Funduszu Kościelnego w latach 1951-2016, in: M. Bielecki (ed.), Kwestie majątkowe w prawie wyznaniowym, Lublin 2018, pp. 29-30.

27 Ł. Bernaciński, Wydatkowanie środków Funduszu Kościelnego w XXI w., "Łódzkie Studia Teologiczne" 2019, no. 28, issue 3, pp. 53-55.

28 Response of the Department of Security of the Ministry of Interior and Administration to the request for public information, reference number DBI-WODO-0667-2-80 / 2021, document in the author's private collection.

29 Sources: $Ł$. Bernaciński, Wydatkowanie..., pp. 53-54; Response..., op. cit. The amounts in the table have been rounded to full zlotys. 


\begin{tabular}{|c|c|c|}
\hline Year & $\begin{array}{c}\text { The budget of the Church Fund entered in } \\
\text { the Budget Act (PLN) }\end{array}$ & $\begin{array}{c}\text { Budget of the Church Fund according } \\
\text { to data from the Ministry of Interior } \\
\text { and Administration (PLN) }\end{array}$ \\
\hline 2013 & 94374000 & $94374000+23856000$ \\
\hline 2014 & 94374000 & $94374000+38769000$ \\
\hline 2015 & 118230000 & $118230000+9829000$ \\
\hline 2016 & 126230000 & $118230000+27209600$ \\
\hline 2017 & 133230000 & $133230000+25538000$ \\
\hline 2018 & 156893000 & $156893000+21190000$ \\
\hline 2019 & 140834000 & $140834000+29947560$ \\
\hline 2020 & 140834000 & $140834000+41016090$ \\
\hline 2021 & 140834000 & 140834000 \\
\hline
\end{tabular}

The continuous nature of this practice cannot be justified by potential errors in annual projections of amounts to be allocated in the following financial year to the Fund's fixed purpose, i.e. payments of a part of social and health insurance contributions for certain groups of the clergy. The more so as, over the years, the budget subsidies for the Fund earmarked in the Budget Act for a given year were often lower than the Fund's spending on its principal purpose in the preceding year. The failure to report actual needs of the Fund to the Minister of Finance was referred to in a report by the Supreme Audit Office as "failure to exercise due diligence". ${ }^{30}$ It can be presumed that the deliberate underrating of the Church Fund's budget in the Budget Act has become an element of a political strategy aimed at hiding the actual annual state budget expenditures on the Fund's purposes from anticlerical constituents. ${ }^{31}$ The media and general public tend to focus their attention on the size of the Church Fund's budget only during the period of drafting and adopting the Budget Act for a given year. Most of the population and journalists have no knowledge of asset transfers from the state budget's special-purpose or general reserve, which leads to increasing the Church Fund's budget in secret from the general public. This presumption is confirmed by the lack of promulgation of decisions on the distribution of funds from the budget increase, which will be described in greater detail further in this paper. Actions of this type represent extreme discretionalism and are detrimental to the standards established in line with the principle of openness in public life.

30 For more information, see D. Walencik, Wydatkowanie..., pp. 33-35 including the literature referenced therein.

31 Ł. Bernaciński, Wydatkowanie..., p. 56. 
It should be noted that the idea of liquidating the Church Fund has been present in the public debate since the 1990s. Since then, attempts have been made to liquidate the Fund several times, but to no avail. In 2013, a draft act amending the act on guarantees of freedom of conscience and religion and some other acts was sent to public consultations and inter-ministerial arrangements, the content of which was to replace the Church Fund with a civil tax deduction. ${ }^{32}$ Also in this case, the change did not take place. ${ }^{33}$

\section{Initiatives eligible for grants from the Church Fund}

The Church Fund awards grants for the maintenance and renovation of historical sacred and ecclesiastical facilities. Projects considered as sacral include construction, extension or reconstruction of a church building or a chapel, as well as adaptation of any other building to sacral purposes. ${ }^{34}$ Adaptation of hospital or prison premises to allow people to take part in a Holy Mass is not considered a sacral project. ${ }^{35}$ In this light, initiative of these types are not eligible for grants from the Church Fund. Since the above legal definition of a sacral project is quite narrow, facilities considered as sacred for the purpose of the Church Fund's operations include those where the faithful gather regularly to exercise religious worship in an organised manner. Facilities considered as ecclesiastical include buildings which accompany sacred facilities and are situated in their vicinity, e.g. buildings which represent the dwelling of a parish priest or rector and a parish chancellery or rectory, buildings which represent the dwelling of curates, buildings which represent the dwelling of secular employees of a parish or rectory (an organist's house), buildings which represent catechetical facilities and buildings of a religious house serving the

32 Draft Act amending the act on guarantees of freedom of conscience and religion and some other acts, https://mc.bip.gov.pl/archiwum-bip-mac/prawo-i-prace-legislacyjne-archiwum/projekty-aktow-prawnych-archiwum/projekt-ustawy-o-zmianie-ustawy-o-gwarancjach-wolnoscisumienia-i-wyznania.html (accessed 11.03.2021).

33 Cf. Ł. Bernaciński, Perspektywy wprowadzenia modelu asygnaty podatkowej do polskiego systemu finansowania kościołów i innych związków wyznaniowych, Warszawa 2021, pp. 88-91.

34 Article 41(2) of the Act of 17 May 1989 on the relations between the State and the Catholic Church in the Republic of Poland, consolidated text, Dz.U. (Journal of Laws) of 2019, item 1347.

35 Article 31(3) and Article 32(2) of the Act of 17 May 1989 on the relations between the State and the Catholic Church in the Republic of Poland, consolidated text, Dz.U. (Journal of Laws) of 2019, item 1347; B. Rakoczy, Ustawa o stosunku państwa do Kościoła Katolickiego w Rzeczypospolitej Polskiej. Komentarz, Warszawa 2008, p. 260. 
purpose of providing pastoral services or aid in the sacred facility concerned ${ }^{36}$ - in the Catholic Church, as well as corresponding buildings in other religious communities. In practice, to have historical value, a building must have features described in the Act on the protection and care of historical monuments. ${ }^{37}$ Article 3(1) of the said Act defines a historical monument as a movable or immovable property, or a part or group thereof, either manmade or human activity-related, which is a testimony to a past epoch or event, and preservation of which lies in the public interest because of its historical, artistic or scientific value. Article 3(6) of the Act defines maintenance works as actions meant to protect and preserve the substance of a historical monument and stop the process of its destruction we well as documentation of these actions. According to the construction law, renovation means construction works in an existing building or structure which are meant to restore it to its original condition but are not routine maintenance, in which other-than-original construction materials may be used..$^{38}$

Due to the aforementioned definition of maintenance works, the Church Fund provided grants primarily for activities focused on the substance of buildings. Since 2017, the granting practice has included also initiatives concerning maintenance of movable furnishings of sacred facilities and fixed elements thereof. ${ }^{39}$ That change has not been duly communicated. Beginning in 2017, the Fund started to accept grant applications for the maintenance of furnishings of sacred facilities, but the change in the granting practice was announced on the Fund's website only after some time. This means failure to meet the directive to communicate the administration's intentions in sufficient advance for stakeholders to be able to safeguard their interests. In this case, a number of applicants who had duly prepared their applications by familiarising themselves with the scope of works eligible for grants from the Fund, did not include any maintenance works concerning movable furnishings. The said failure to communicate the intention to change the granting practice led to inequality among the applicants in a given year, putting those who duly prepared their applications in a disadvantaged position.

36 Article 60(2) of the of the Act of 17 May 1989 on the relations between the State and the Catholic Church in the Republic of Poland, consolidated text, Dz.U. (Journal of Laws) of 2019, item 1347.

37 Act of 23 July 2003 on the protection and care of historical monuments, consolidated text, Dz.U. (Journal of Laws) of 2020, item 282.

38 Article 3(8) of the Act of 7 July 1994 on the Construction Law, consolidated text, Dz.U. (Journal of Laws) of 2019, item 1186.

39 For more information, see Ł. Bernaciński and J. Wojtasik, Beneficjenci dotacji udzielanych z Funduszu Kościelnego w latach 2016-2018, "Gubernaculum et Administratio" 2019, vol. 19, no. 1, p. 95. 
The Church Fund awards grants also for socially useful ecclesiastical activities which involve, principally, running homes for orphans, elderly people, physically or mentally disabled and other categories of people who need care; running hospitals, other medical institutions and pharmacies; organising assistance in maternity protection; organising aid to orphans, victims of natural disasters and epidemics, victims of wars, families and people who are impoverished or in a difficult health situation, including people deprived of their liberty; running nurseries, orphan care homes, dormitories and shelters; providing assistance in ensuring leisure for children and youth in need; promoting the idea of helping others and promoting social attitudes which contribute to it; providing aid to victims of natural disasters and people in dire need abroad. ${ }^{40}$ In order to effectively perform the aforementioned activities, churches and other religious associations have the right to establish and run, in accordance with applicable legislation, appropriate institutions, including facilities for those in need of care, hospitals and other medical institutions within the meaning of regulations on medical activities, as well as nurseries and shelters for children. ${ }^{41}$ Grants from the Church Fund cover mainly works which involve adaptation, modernisation, renovation, construction or extension of the aforementioned facilities run by churches and other religious societies. Practice shows that the Fund awards grants also for participation of beneficiaries of socially useful ecclesiastical activities in summer camps and clubs, furnishing of classrooms and purchase of teaching materials and, occasionally, for kitchen equipment, meals or admission tickets. In principle, the Fund does not finance any costs of the up-keeping of the aforementioned facilities, but such support is not ruled out in specially justified cases. In this respect, the practice is relatively stable and uniform.

\section{The procedure for awarding grants from the Church Fund}

Entities eligible to receive grants from the Church Fund include legal persons of legally recognised churches and other religious associations. This means churches and other faith communities whose relations with the state are regulated under separate legislative acts as well as those entered in the Register of Churches and

40 Article 39 of the Act of 17 May 1989 on the relations between the State and the Catholic Church in the Republic of Poland, consolidated text, Dz.U. (Journal of Laws) of 2019, item 1347.

41 Article 24(1) of the Act of 17 May 1989 on the guarantees of the freedom of conscience and religion, consolidated text, Dz.U. (Journal of Laws) of 2017, item 1153. 
Religious Associations. ${ }^{42}$ Grants are awarded on the basis of applications. Eligible entities submit their applications on an official form directly to the Church Fund's Board or through representations of their churches or other religious associations to the Fund. The Church Fund's statute provides also for authorising the Fund's Board to award grants on its own initiative, but it is a defunct provision. ${ }^{43}$

Applications submitted by the prescribed call deadline ${ }^{44}$ are checked for compliance with the formal requirements and subjected to preliminary evaluation. In the case of any deficiencies, the applicant is informed of the deadline to rectify them, and if they are not rectified by that deadline, the documentation is returned to the applicant. The applicant is informed if the application cannot be processed due to failure to meet the formal requirements.

At the next stage, the Director of the Department appoints a commission which he or she chairs. The commission includes also a vice chair and two members Department employees. The commission recommends applications, including grant amounts, to the Minister of Internal Affairs and Administration. Decisions regarding recommendations are made in an open vote by simple majority. In the event of an even distribution of votes, the chair of the commission has the decisive vote. In their deliberations, members of the commission are allowed to consult outside experts and other Department employees. The commission may also request applicants, either directly or indirectly, to clarify and supplement their applications and annexes thereto. Additionally, a visit to the facility referred to in the application is allowed to compare its state of preservation with the application documents and to assess the actual needs. ${ }^{45}$ When analysing applications and formulating recommendations, the commission relies on the following criteria:

a) the Church Fund's budget allocated to grants;

b) conformance of the purpose applied for with the scope of tasks performed by the Fund;

42 Cf. Articles 30-31 of the Act of 17 May 1989 on the guarantees of the freedom of conscience and religion, consolidated text, Dz.U. (Journal of Laws) of 2017, item 1153.

43 Section 8 of the Statutes of the Church Fund.

44 Application call deadlines are announced by the Minister of Internal Affairs and Administration. To meet the deadline, applicants can simply send their applications at a Polish post office before the lapse of the deadline. Where justified (due to a random event or important public interest), the Minister may accept an application submitted after the deadline.

45 M. Zawiślak, Prawne i finansowe aspekty działalności Funduszu Kościelnego w latach 1989-2009, in: D. Walencik (ed.) Prawo wyznaniowe w Polsce (1989-2009). Analizy-dyskusje-postulaty, Katowice - Bielsko-Biała 2009, pp. 365-366. 
c) the current technical condition of the facility referred to in the grant application, in particular the level of threat to the facility if it requires renovation;

d) the actual ability to complete the works included in the application by the end of the calendar year;

e) whether the expected costs of the works included in the application are reasonable as well as the applicant's financial commitment and identification of other sources of financing by the applicant;

f) the scale of the task included in the application and the progress in its implementation.

At its meetings, the commission discusses the analyses of respective applications, selects applications and prepares a list of recommended applications with proposed grant amounts. These lists represent a draft decision of the Minister of Internal Affairs and Administration regarding grants to be awarded. Within maximum seven days from the commission's meeting, the chair of the commission submits the lists to the Minister of Internal Affairs and Administration in order for the Minister to make a decision on awarding grants from the Church Fund. When deciding about grants and amounts thereof, the Minister of Internal Affairs and Administration relies on the following equivalent criteria ${ }^{46}$ :

a) the Church Fund's budget allocated to grants;

b) the current technical condition of the building referred to in the grant application;

c) findings of inspections conducted at the applicant's registered office or the site of works referred to in the application;

d) the scale of the task included in the application and the progress in its implementation;

e) social demand for the project referred to in the application and the financial capacity of the local community;

f) the impact of the project referred to in the application on the local community;

g) the significance of the historical-grade facility referred to in the application to preservation and protection of the cultural heritage;

h) settlement of accounts for previous grants, if awarded.

46 At present, the criteria on which the commission relies when analysing applications and formulating recommendations, and the criteria on which the Minister of Internal Affairs and Administration relies when deciding about grants and amounts thereof are published on the Church Fund's website. As pointed out by D. Walencik, in 2016 applicants were not informed of the substantive criteria used for assessing their applications (D. Walencik, Wydatkowanie..., op. cit., p. 37), although these criteria had already been known and used before - cf. T. Stanisławski, Finansowanie..., op. cit., p. 129. 
Decisions of the Minister of Internal Affairs and Administration are published on the Ministry's website. In practice, however, only decisions regarding grants from sources other than the special-purpose or general reserve of the state budget are published. ${ }^{47}$ Funds obtained in such a manner are allocated by way of the same procedure, but the related decisions of the Minister of Internal Affairs and Administration are not communicated openly. Failure to publish certain decisions can be detected only by comparing the total value of grants awarded with the sum of grants communicated in the published decisions. The fact that those certain decisions are not published means that their beneficiaries are also unknown to the public. The hidden true amount of grants awarded by the Fund and some of the beneficiaries of those grants cannot be uncovered by the general public, journalists or even some of the scholars and commentators who study the Church Fund.

It should also be added that applicants are informed in writing if they have been awarded grants from the Church Fund, including the purpose for which a respective grant has been awarded. ${ }^{48}$ Based on decisions made by the Minister of Internal Affairs and Administration, draft agreements with applicants are prepared to include provisions on the purpose and amount of the grant, the manner of its transfer and the date by which it must be used. Such an agreement regulates the manner in which the progress in works may be checked as well as dates and rules regarding settlement of accounts for the grant and possible return of the unused portion. ${ }^{49}$ Section 10 of the Church Fund's statute rules that grants from the Church Fund are provided on a cashless basis and are subject to settlement of accounts with the Fund's Board within 12 months under the provisions of generally applicable financial and accounting regulations. The deadline may be extended in special cases with the consent of the Board of the Church Fund.

\section{Conclusions}

Legal persons of all churches and other religious associations with regulated relationships with the State are eligible to receive grants from the Church Fund.

47 Information of 8 March 2019 provided by the Ministry of Internal Affairs and Administration in response to a request for access to public information (ref. no DBI-WODO-0667-3-7/2019). The document is in the private collection of the author of this paper.

48 Benefits provided from the Fund are earmarked benefits within the meaning of Article 127(1)(1) (b) of the Act of 27 August 2009 on the public finance, consolidated text, Dz.U. (Journal of Laws) of 2019, item 869.

49 M. Piszcz-Czapla, Kryteria wydatkowania środków Funduszu Kościelnego, "Studia z Prawa Wyznaniowego" 2009, vol. 12, p. 350. 
Although such a wide definition of the discussed circles is inconsistent with the Act on property in mortmain, it is justified by implementation of the constitutional principles of equality of churches and other religious associations and cooperation between them and the state for the individual and the common good. The Church Fund awards grants for the reconstruction, maintenance and renovation of sacred facilities of historical value and for ecclesiastical charity and care activities. Since the establishment of the Fund, its budget has been built entirely on subsidies from the state budget. Recent years have seen a new practice of increasing Church Fund's budget during the financial year by subsidising it from either the specialpurpose or general reserve of the state budget. Furthermore, decisions regarding grants awarded from the Fund's budget increase are not published on the Fund's website. This coherent action should be considered as deliberate concealment of the amounts spent by the Church Fund from the public. The area related to the financing of the Fund should be considered as non-transparent. Unfortunately, this ascertainment has remained valid since the very establishment of the Fund, and neither the change of Poland's political system nor subsequent changes of governments after 1990 have managed to abolish it.

The transparency of the Church Fund's grant award procedure deserves credit. Although quite complicated, the procedure seems to be transparent and is communicated to applicants in an appropriate and comprehensible manner. It should be said that the definitions of historical sacred and ecclesiastical facilities have been based strictly on the existing legislation rather than on some new concepts developed for the Fund's own purposes. The same applies to the definition of categories of entities which perform ecclesiastical charity and care activities. If the formal requirements are not met, the applicant is duly notified, which allows them to modify the application and reapply for a grant. Also, the criteria to be followed by the commission have been defined, where the commission recommends applications to the Minister of Internal Affairs and Administration before final grant decisions are made. Since these criteria are to a large extent assessment-based, applicants should be allowed to view the results of the selection procedure in an uncomplicated manner and to be informed of the reasons for which their applications have been rejected. One should also consider introducing the option to modify an application to the extent indicated by the commission. This would contribute to increasing the openness of the grant award procedure and, more importantly, would build a dialogue between the administration and applicants and increase the citizens' trust in the state. 


\section{References}

Abramowicz A.M., Zasada równouprawnienia związków wyznaniowych w orzecznictwie Trybunału Konstytucyjnego, "Studia z Prawa Wyznaniowego" 2015, vol. 18.

Bernaciński Ł., Perspektywy wprowadzenia modelu asygnaty podatkowej do polskiego systemu finansowania kościołów i innych związków wyznaniowych, Warszawa 2021.

Bernaciński Ł., Wydatkowanie środków Funduszu Kościelnego w XXI w., "Eódzkie Studia Teologiczne" 2019, vol. 28, issue 3.

Bernaciński Ł., Wojtasik J., Beneficjenci dotacji udzielanych z Funduszu Kościelnego w latach 2016-2018, "Gubernaculum et Administratio" 2019, vol. 19, issue 1.

Borecki P., Pietrzak M., Glosa do wyroku TK z dnia 2 kwietnia 2003 r., K 13/02, "Przegląd Sejmowy" 2003, vol. 5.

Czohara A., Podstawy prawne zadań Funduszu Kościelnego w III RP, in: P. Borecki et al. (eds.), Pro bono Reipublicae. Księga jubileuszowa Prof. Michała Pietrzaka, Warszawa 2009.

Koredczuk J., Entry: Dotacje państwowe dla związków wyznaniowych, in: A. Mezglewski (ed.), Leksykon prawa wyznaniowego, Warszawa 2014.

Krukowski J., Polskie prawo wyznaniowe, Warszawa 2008.

Mastalski R., Prawo podatkowe, Warszawa 2016.

Mezglewski A., Misztal H., Stanisz P., Prawo wyznaniowe, Warszawa 2011.

Osowski Sz., Wilk B., Jawność jako zasada demokratycznego państwa prawnego, "Krajowa Rada Sądownictwa” 2016, vol. 4.

Piszcz-Czapla M., Kryteria wydatkowania środków Funduszu Kościelnego, "Studia z Prawa Wyznaniowego" 2009, vol. 12.

Rakoczy B., Ustawa o stosunku państwa do Kościoła Katolickiego w Rzeczypospolitej Polskiej. Komentarz, Warszawa 2008.

Rynkowski M., Państwo i Kościół w Polsce, in: G. Robbers (ed.), Państwo i kościół w krajach Unii Europejskiej, Wrocław 2007.

Stanisławski T., Finansowanie instytucji wyznaniowych ze środków publicznych $w$ Polsce, Lublin 2011.

Stanisławski T., Sposoby finansowania kościołów i innych związków wyznaniowych ze środków publicznych, in: D. Walencik (ed.), Prawo wyznaniowe w Polsce (1989-2009). Analizy - dyskusje - postulaty, Katowice-Bielsko-Biała 2009.

Stanisz P., Bezstronność światopogladowa władz publicznych a finansowanie związków wyznaniowych, in: T.J. Zieliński (ed.), Bezstronność religijna, światopogladowa i filozoficzna władz Rzeczypospolitej Polskiej, Warszawa 2009.

Walencik D., Nieruchomości Kościoła katolickiego w Polsce w latach 1918-2012. Regulacje prawne - nacjonalizacja - rewindykacja, Katowice 2013.

Walencik D., Rewindykacja nieruchomości Kościoła katolickiego w postępowaniu przed Komisją Majątkową, Lublin 2008. 
Walencik D., Wydatkowanie środków Funduszu Kościelnego w latach 1951-2016, in: M. Bielecki (ed.), Kwestie majatkowe w prawie wyznaniowym, Lublin 2018.

Winiarczyk-Kossakowska M., Przejęcie przez państwo "dóbr martwej ręki” (W pięćdziesiąta rocznicę), "Państwo i Prawo" 2000, No. 12.

Zawiślak M., Prawne i finansowe aspekty działalności Funduszu Kościelnego w latach 1989-2009, in: D. Walencik (ed.), Prawo wyznaniowe w Polsce (1989-2009). Analizy-dyskusje-postulaty, Katowice-Bielsko-Biała 2009.

Zawiślak M., Wydatkowanie środków Funduszu Kościelnego w latach 1950-1989, “Studia z Prawa Wyznaniowego" 2009, vol. 12.

Zielińska E., Transparentność, in: J. Itrich-Drabarek (ed.), Encyklopedia administracji publicznej, Warszawa 2018.

\section{CITATION}

Bernaciński Ł., Assessment of the transparency of the functioning of the Church Fund in Poland in terms of granting it, "Acta Iuris Stetinensis" 2021, No. 2 (Vol. 34), 9-25,

DOI: 10.18276/ais.2021.34-01. 